\title{
Transformation and Excretion of Drugs in Biological Systems. V.1) Correlation between Renal Excretion and Biotransformation of Sulfadimethoxine
}

\author{
Takaichi Arita, Ryohei Hori, ${ }^{2 a)}$ Masahiko Takada, \\ and Ayako Misawa ${ }^{2 b)}$ \\ Faculty of Pharmaceutical Science, Hokkaido University ${ }^{2 a)}$ \\ and Pharmacy, Hokkaido University Hospital $\left.{ }^{2 b}\right)$
}

(Received September 22, 1970)

\begin{abstract}
Sulfadimethoxine and its three biotransformed products in man were applied to renal clearance experiments in dogs to elucidate their renal excretion mechanisms.

Clearance ratio of sulfadimethoxine is extremely low compared with each biotransformed product. Of three biotransformed products, clearance ratio of sulfadimethoxine- $\mathrm{N}^{\mathbf{1}}$ glucuronide greatly exceeded over the clearance ratio of the other two biotransformed products.

Considerable proximal tubular secretion of sulfadimethoxine- $\mathrm{N}^{4}$-acetate was observed. On the contrary, the proximal tubular secretion of sulfadimethoxine- $\mathrm{N}^{1}$-glucuronide and sulfadimethoxine were insufficient.

Sulfadimethoxine- $\mathrm{N}^{1}$-glucuronide considerably reduced the affinity to dog plasma protein compared with sulfadimethoxine and sulfadimethoxine- $\mathrm{N}^{4}$-acetate.
\end{abstract}

As one of the long-acting sulfonamides, sulfadimethoxine has been widely applied to clinical treatment of various bacterial infections. In the view of clinical usefulness and pharmacological interest, intensive researches on metabolic fate of sulfadimethoxine have been carried out by many investigators ${ }^{3-7}$ ) and it was shown that the major metabolite of sulfadimethoxine in man is rather water-soluble $\mathrm{N}$-glucuronide than water-insoluble acetyl derivatives, whereas many other sulfonamides tend to suffer acetyl conjugation which is potential of renal damage. Several papers ${ }^{8,9)}$ dealt also with renal excretion of sulfadimethoxine, but the preceding studies tend to neglect renal handling of the biotransformed products, thus the detail of excretory behaviors of the drug is still remained to be quite obscure. For the purpose of clarifying the renal handling of sulfadimethoxine and its biotransformed products and obtaining the information concerning the mechanism of long action of the drug, the manners by which dog kidney handles sulfadimethoxine and its three biotransformed products in man have been investigated in detail.

Furthermore, the correlation between their molecular structural characteristics and the susceptibility to renal transport was discussed.

\section{Experimental}

Preparation of Materials_-Sulfadimethoxine: Commercially available sulfadimethoxine was recrystallized from EtOH. mp 200 . Sulfadimethoixne- $\mathrm{N}^{4}$-acetate: Sulfadimethoxine- $\mathrm{N}^{4}$-acetate was synthe-

1) Part IV: T. Arita, R. Hori, K. Ito, and H. Sekikawa, Chem. Pharm. Bull. (Tokyo), 18, 1675 (1970).

2) Location: a) Nishi-6-chome, Kita-12-jo, Sapporo; b) Nishi-5-chome, Kita-14-jo, Sapporo.

3) J.W. Bridges, M.R. Kibby, and R.T. Williams, Biochem. J., 91, 12 (1964).

4) T. Uno, T. Kishima, and M. Fujimoto, Chem. Pharm. Bull. (Tokyo), 13, 261 (1965).

5) J.W. Bridges, M.R. Kibby, and R.T. Williams, Biochem. J., 96, 829 (1965).

6) T. Uno, T. Kushima, and T. Hiraoka, Chem. Pharm. Bull. (Tokyo), 15, 1272 (1967).

7) J.W. Bridges, M.R. Kibby, S.R. Walker, and R.T. Williams, Biochem. J., 109, 851 (1968).

8) M. Sugita, Nippon Jinzōgaku Kaishi, 5, 235 (1963).

9) K. Yamamoto, J. Kurosawa, M. Kishigami, T. Yoshizaki, T. Kitakaze, and T. Dozaki, Saishin-Igaku, 14, 3147 (1959). 
sized $\left.^{10}\right)$ by acetylation of sulfadimethoxine. $\mathrm{mp} 208-210^{\circ}$. Sulfadimethoxine- $\mathrm{N}^{4}$-glucuronide: Sulfadimethoxine $(6.3 \mathrm{~g})$ and sodium glucuronate $(2.4 \mathrm{~g})$ were reacted by the method of Bridges, et al.,5) but it was difficult to purify. Then, the solvent of the reaction mixture was evaporated in vacuo at $37^{\circ}$ to gain oily substance. Thirty $\mathrm{ml}$ of $\mathrm{H}_{2} \mathrm{O}$ was added to the substance and precipitate (unreacted sulfadimethoxine) was discarded by filtration. One hundred $\mathrm{ml}$ of acetone was added to the filtrate and restored at $0^{\circ}$ overnight. Yellow oily substance was obtained by decantation and the substance was dissolved in $20 \mathrm{ml}$ of $0.02 \mathrm{~N} \mathrm{NH}_{4} \mathrm{OH}$ and applied to Kieselgel GF thin-layer plates and were developed with the solvent of PrOH$\mathrm{H}_{2} \mathrm{O}-\mathrm{NH}_{4} \mathrm{OH}(6: 2: 1)$. The plates were dried, and the $R f$ part of sulfadimethoxine- $\mathrm{N}^{4}$-glucuronide was checked by illumination of ultraviolet ray, scraped, eluted with $1 / 15 \mathrm{~m}$ isotonic phosphate buffer solution and the solution immediately applied to clearance experiments to obviate its rapid hydrolysis. Sulfadimethoxine- $\mathrm{N}^{4}$-glucuronide was also identical with previously reported data in paper chromatography.5)

Isolation and Purification of Sulfadimethoxine- $\mathbf{N}^{1}$-glucuronide from Human Urine-_-Six male volunteers each took $3 \mathrm{~g}$ of sulfadimethoxine a day orally and their urine (16 liters) was collected for $48 \mathrm{hr}$. The urine was treated with charcoal and applied to lead salt precipitation procedure to obtain red brown substance by the method of Uno, et al.4) Attempts to purify the substance from several solvents were finally unsuccessful. Then, the substance was applied to Kieselgel GF thin-layer plates (1 $\mathrm{mm}$ in thickness, activated at $110^{\circ}$ for $1 \mathrm{hr}$ ) and were developed with the solvent system of $\mathrm{PrOH}-\mathrm{H}_{2} \mathrm{O}-\mathrm{NH}_{4} \mathrm{OH}(6: 2: 1)$. The plate was dried, $R f$ part of sulfadimethoxine- $\mathrm{N}^{1}$-glucuronide was checked by illumination of ultraviolet ray, scraped, collected, and eluted with 1.5 liters of $\mathrm{MeOH}$. The eluate was filtered with Filter-cel, and the filtrate was evaporated to dryness under reduced pressure below $37^{\circ}$. The residue was again dissolved in little amounts of $\mathrm{MeOH}$ in order to discard contaminated silica gel, and the solvent was evaporated under reduced pressure below $37^{\circ}$. Yellow amorphous substance was obtained $(1.2 \mathrm{~g})$. mp $160-170^{\circ}$. Anal. Calcd. for $\mathrm{C}_{18} \mathrm{H}_{27}-$ $\mathrm{O}_{11} \mathrm{~N}_{5} \mathrm{~S}$ (ammonium sulfadimethoxine- $\mathrm{N}^{1}$-glucosiduronate monohydrate): $\mathrm{C}, 41.45 ; \mathrm{H}, 5.22$. Found: C, 41.24; H, 5.75. This substance did not reduce Benedict's solution nor Fehling's solution. This substance was also identical with previously reported data in ultraviolet spectrum and infrared spectrum. $\left.{ }^{4}\right)$

Thin-Layer Chromatography_-The samples were applied to Kieselgel GF plates $(0.5-1.0 \mathrm{~mm}$ in thickness, activated at $110^{\circ}$ for $1 \mathrm{hr}$ ), and were developed with the solvent systems of (1) $\mathrm{PrOH}-\mathrm{H}_{2} \mathrm{O}-$ $\mathrm{NH}_{4} \mathrm{OH}(6: 2: 1)$, (2) $\mathrm{CHCl}_{3}-\mathrm{MeOH}(5: 1)$, (3) iso- $\mathrm{PrOH}-\mathrm{NH}_{4} \mathrm{OH}-\mathrm{H}_{2} \mathrm{O}(20: 1: 2)$, and (4) $\mathrm{PrOH}_{-} \mathrm{NH}_{4} \mathrm{OH}$ $(7: 3)$. The plate was dried and sprayed with the following color reagents.

(1) Tsuda Reagent: $0.1 \% \mathrm{~N}$-(2-dimethylaminoethyl)-1-naphthylamine oxalate aqueous solution was sprayed after $3 \mathrm{~N} \mathrm{HCl}, 0.2 \% \mathrm{NaNO}_{2}$ and $0.2 \%$ ammonium sulfamate were sprayed.

(2) Naphthoresorcinol Picrate Reagent: $1 \%$ naphthoresorcinol picrate in EtOH to which equal volume of $20 \% \mathrm{H}_{2} \mathrm{SO}_{4}$ was added before spraying. After spraying the reagent, the thin-layer plates were heated at $105^{\circ}$ for $10 \mathrm{~min}$.

Paper Chromatography_Chromatography on Toyō Roshi No. $51(2 \times 40 \mathrm{~cm})$ was used. The solvent systems employed were (1) EtOH- $\mathrm{H}_{2} \mathrm{O}(8: 2)$, (2) $\mathrm{BuOH}-\mathrm{NH}_{4} \mathrm{OH}-\mathrm{H}_{2} \mathrm{O}(10: 1: 1)$, and (3) $\mathrm{BuOH}-\mathrm{AcOH}-\mathrm{H}_{2} \mathrm{O}$ $(4: 2: 2)$. The paper was dried and sprayed with the following color reagent.

(1) Ehrlich's Reagent: $2 \mathrm{~g}$ p-dimethylaminobenzaldehyde in $2 \mathrm{ml}$ conc. $\mathrm{HCl}$ and $98 \mathrm{ml} \mathrm{EtOH.}$

(2) Tsuda's Reagent: This reagent was used as mentioned above.

(3) Naphthoresorcinol Picrate Reagent: Mixed solution of 1\% naphthoresorcinol picrate EtOH solution and $2 \%$ trichloroacetic acid aqueous solution.

Animal Experiments-Standard methods ${ }^{8,11)}$ for renal clearance were employed. Male and female dogs weighing $9.5-25.0 \mathrm{~kg}$ were used in these experiments. Pentobarbital sodium in doses of $30 \mathrm{mg} / \mathrm{kg}$ was administered to the animal as an anesthetic reagent through cephalic vein. Urine was collected in glass cylinder from small polyethylene catheters in the lower third of either of ureters through a $5 \mathrm{~cm}$ midline suprapubic abdominal incision. In all experiments, the dogs were primed with sulfadimethoxine or its biotransformed products $(50-200 \mathrm{mg} /$ body $)$, inulin $(1 \mathrm{~g} /$ body $)$ and mannitol $(2 \mathrm{~g} /$ body $)$ through cephalic vein, successively a sustaining infusion of sulfadimethoxine or its biotransformed products $(0.03 \%)$, inulin $(0.3 \%)$ and mannitol $(5 \%)$ in saline or isotonic phosphate buffer ( $\mathrm{pH} 7.4)$ was continued throughout the experiment at the rate of $3 \mathrm{ml} / \mathrm{min}$.

For blockade of proximal tubular secretion of the drugs, iodopyracet $(208 \mathrm{mg} / \mathrm{kg})$ was primed through .cephalic vein after two or three control clearance periods, and a sustaining infusion of iodopyracet $(6.81 \mathrm{mg} /$ $\mathrm{kg} / \mathrm{min}$ ) was continued at the rate of $3 \mathrm{ml} / \mathrm{min}$, until the experiment was performed. ${ }^{11,12)}$ Blood samples were drawn at the midpoint of each 10-20 min clearance period from femoral artery. Plasma was separated by immediate centrifugation. Plasma and urine samples were deproteinized with $10 \%$ trichloroacetic acid, and then analyzed as follows: Sulfadimethoxine and its biotransformed products by diazotization, ${ }^{13)}$ inulin by

10) T. Uno and M. Ueda, Yakugaku Zasshi, 80, 1785 (1960).

11) M. Fujimoto, Nippon Rinsho, 25, 1154 (1967).

12) F. Portwich, H. Buttner, and K. Engelhardt, Klin. Wschr., 41, 447 (1963).

13) T. Koizumi, T. Arita, and K. Kakemi, Chem. Pharm. Bull. (Tokyo), 12, 413 (1964). 
a modification of the method described by Dische, et al., ${ }^{14)}$ and iodopyracet by the titration method described by Alpert. ${ }^{15)}$ Hitachi-Horiba model $\mathrm{F}-4 \mathrm{pH}$ meter with a glass electrode was used to determine $\mathrm{pH}$ of urine. Drug clearance $(C)$ in $\mathrm{ml} / \mathrm{min}$ is calculated as $C=U V / P$, where $U$ and $P$, and $V$ indicate urine and plasma concentration of the drug in $\mathrm{mg} / \mathrm{ml}$, and urine flow rate in $\mathrm{ml} / \mathrm{min}$, respectively. To estimate the renal handling for the drug, clearance ratio (CR) has been conventionally used and is expressed as $C R=C /-$ $G F R$, where $G F R$ represents glomerular filtration rate in $\mathrm{ml} / \mathrm{min}$ calculated as inulin clearance.

Protein Binding - The extent of binding of sulfadimethoxine and its biotransformed products to dog plasma was determined by the method of equilibrium dialysis as described previously. ${ }^{16)}$ The medium used was $0.1 \mathrm{M}$ isotonic phosphate buffer at $\mathrm{pH} 7.4 .^{13}$ ) The outer compartment contained the isotonic phosphate buffer containing sulfonamides at several concentrations in a total volume of $4 \mathrm{ml}$. The inner compartment (visking cellulose tubing) contained $2 \mathrm{ml}$ of dog plasma. Incubation was carried out for 24 hours at $37^{\circ}$ with mild shaking. Upon the attainment of equilibrium time the compartments were separated and analyzed for diazotiable amine.

\section{Result and Discussion}

\section{Renal Excretion of Sulfadimethoxine and Its Biotransformed Products}

Renal clearance experiments of sulfadimethoxine, sulfadimethoxine- $\mathrm{N}^{4}$-acetate, sulfadimethoxine- $\mathrm{N}^{4}$-glucuronide and sulfadimethoxine- $\mathrm{N}^{1}$-glucuronide were undertaken. The results are shown in Fig. $1-4$ respectively. The detailed data of each compound is also exemplified in Table I-IV respectively. As shown in Fig. 1 and Table I, it is noteworthy

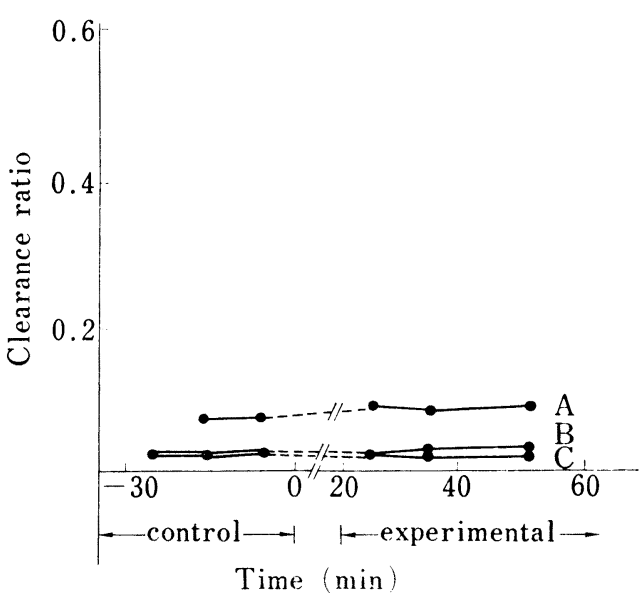

Fig. 1. Clearance Ratio of Sulfadimethoxine before and after Blockade of Proximal Tubular Secretion

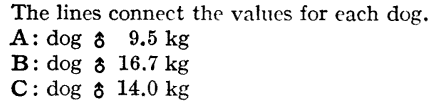
that clearance ratio of sulfadimethoxine is extremely low to certify the predominant distal tubular reabsorption. Thus, high plasma concentration of sulfadimethoxine is maintained for long time, which shows prolonged pharmacological effect in vivo. The alteration of clearance ratio of sulfadimethoxine before and after blockade of proximal tubular secretion by iodopyracet was not observed as shown, which suggests that active secretion of sulfadimethoxine by proximal tubule is insufficient.

On biotransformation of sulfadimethoxine in man, it is well established that $\mathrm{N}^{1}$-glucuronide of sulfadimethoxine is the major metabolite. On the other hand, $\mathrm{N}^{4}$-acetate and $\mathrm{N}^{4}$-glucuronide of sulfadimethoxine are excreted as minor biotransformed products. Accordingly, the renal excretion behaviors of these three biotransformed products have to confirm in order to explain the overall urinary excretion pattern of sulfadimethoxine.

As shown in Fig. 2 and Table II, acetylation of $\mathrm{N}^{4}$-amino group of sulfadimethoxine causes distinct increase of clearance ratio and considerable secretion by proximal tubule as compared with sulfadimethoxine, indicating that proximal tubular secretion is the main excretory route. It is very interesting that, in spite of relatively reduced solubility of sulfadimethoxine- $\mathrm{N}^{4}$ acetate in body fluids compared with sulfadimethoxine, clearance ratio of the former is considerably higher than the latter. Sulfadimethoxine- $\mathrm{N}^{4}$-glucuronide, which is one of the-

14) Z. Dische and E. Borenfreund, J. Biol. Chem., 192, 583 (1951).

15) L.K. Alpert, Bull. Johns Hopkins Hosp., 68, 522 (1941).

16) M. Nakagaki, N. Koga, and H. Terada, Yakugaku Zasshi, 83, 586 (1963). 
TABLE I. Clearance Ratio of Sulfadimethoxine before and after Blockade of Proximal Tubular Secretion

\begin{tabular}{|c|c|c|c|c|c|c|c|c|}
\hline & \multirow{2}{*}{$\begin{array}{l}\text { Time } \\
\text { (min) }\end{array}$} & \multirow{2}{*}{$\begin{array}{c}V \\
(\mathrm{ml} / \mathrm{min})\end{array}$} & \multirow{2}{*}{$\begin{array}{c}\text { Urine } \\
\mathrm{pH}\end{array}$} & \multirow{2}{*}{$\begin{array}{c}G F R \\
(\mathrm{ml} / \mathrm{min})\end{array}$} & \multicolumn{4}{|c|}{ Sulfadimethoxine } \\
\hline & & & & & $\underset{(\mathrm{mg} / \mathrm{ml})}{\overparen{U}}$ & $\begin{array}{c}P \\
(\mathrm{mg} / \mathrm{ml})\end{array}$ & $\begin{array}{c}C \\
(\mathrm{ml} / \mathrm{min})\end{array}$ & CR \\
\hline \multirow{3}{*}{ Control } & $(30-20$ & 2.41 & 7.00 & 55.7 & 0.0550 & 0.0700 & 1.89 & 0.034 \\
\hline & $\{20-10$ & 2.46 & - & 65.3 & 0.0520 & 0.0726 & 1.76 & 0.027 \\
\hline & $10-0$ & 2.44 & - & 60.0 & 0.0551 & 0.0756 & 1.78 & 0.030 \\
\hline \multirow{3}{*}{ Exptl. ${ }^{a)}$} & $20-30$ & 3.58 & 7.10 & 78.1 & 0.0400 & 0.0650 & 2.20 & 0.028 \\
\hline & $\{30-40$ & 3.24 & - & 62.7 & 0.0494 & 0.0624 & 2.57 & 0.041 \\
\hline & $40-60$ & 2.87 & 7.00 & 66.6 & 0.0495 & 0.0718 & 1.97 & 0.030 \\
\hline
\end{tabular}

dog: ô $16.7 \mathrm{~kg}$ (dog B in Fig. 1)

a) iodopyracet: $3.47 \mathrm{~g}$ i.v., $100 \mathrm{mg} / \mathrm{min}$ infusion

minor biotransformed products in sulfadimethoxine, was chemically synthesized, and applied to renal clearance experiments. The results are shown in Fig. 3 and Table III. This substance also causes distinct increase of clearance ratio as well as sulfadimethoxine- $\mathrm{N}^{4}$-acetate.

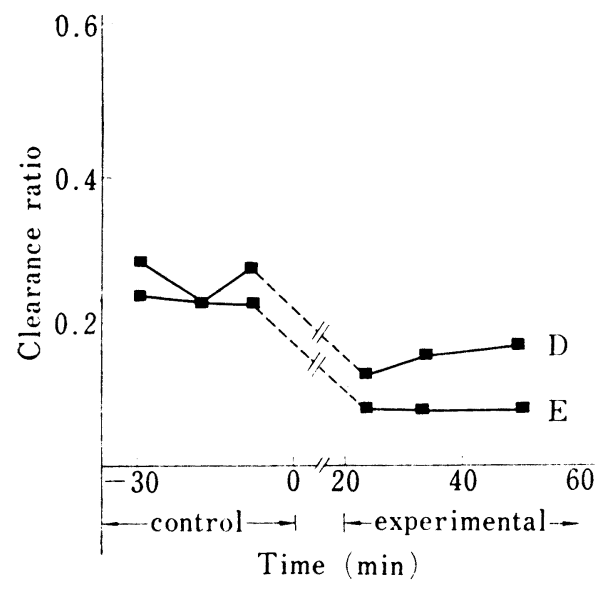

Fig. 2. Clearance Ratio of Sulfadimethoxine- $\mathrm{N}^{4}$-acetate before and after Blockadeof Proximal Tubular Secretion

The lines connect the values for each dog.

$\mathrm{D}: \operatorname{dog} \& 12.0 \mathrm{~kg}$

$\mathrm{E}: \mathrm{dog}$ o $14.3 \mathrm{~kg}$

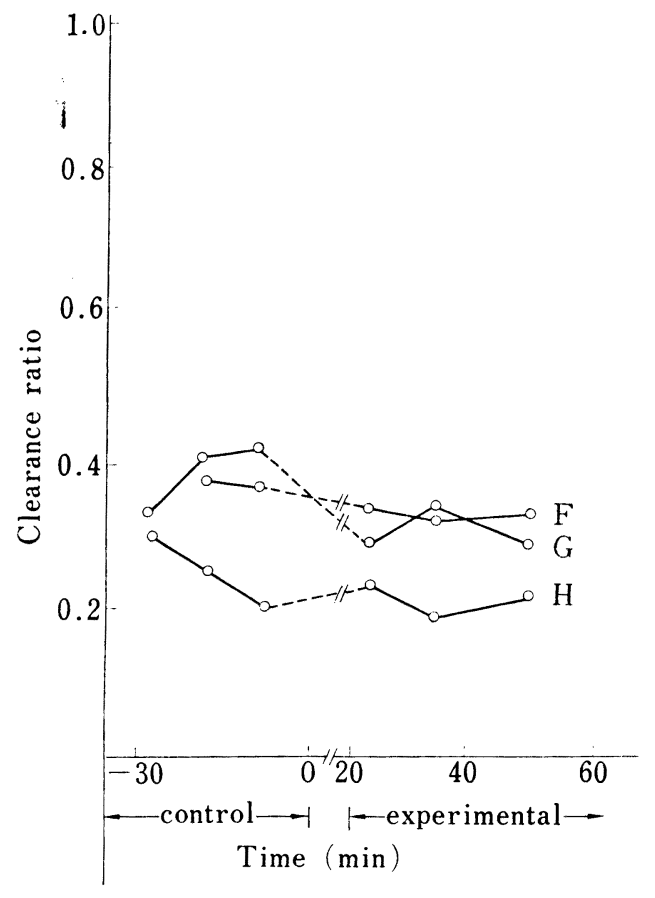

Fig. 3. Clearance Ratio of Sulfadimethoxine$\mathrm{N}^{4}$-glucuronide before and after Blockade of Proximal Tubular Secretion

The lines connect the values for each dog.

$\mathrm{F}: \operatorname{dog} \& 11.5 \mathrm{~kg}$

G: $\operatorname{dog} \& 14.0 \mathrm{~kg}$

$\mathrm{H}: \operatorname{dog}$ ㅇ $19.2 \mathrm{~kg}$

Biosynthesized sulfadimethoxine- $\mathrm{N}^{\mathbf{1}}$-glucuronide which is major biotransformed product in sulfadimethoxine was also applied to renal clearance experiments. The results are shown in Fig. 4 and Table IV. N1-Glucuronidation of sulfadimethoxine causes great increase of clearance ratio compared with sulfadimethoxine and the other two biotransformed products. The alteration of clearance ratio before and after blockade of proximal tubular secretion by 
TABLE II. Clearance Ratio of Sulfadimethoxine-N4-acetate before and after Blockade of Proximal Tubular Secretion

\begin{tabular}{|c|c|c|c|c|c|c|c|c|c|}
\hline & \multirow[b]{2}{*}{$\begin{array}{l}\text { Time } \\
(\min )\end{array}$} & \multirow[b]{2}{*}{$\begin{array}{c}V \\
(\mathrm{ml} / \mathrm{min})\end{array}$} & \multirow[b]{2}{*}{$\begin{array}{l}\text { Urine } \\
\mathrm{pH}\end{array}$} & \multirow[b]{2}{*}{$\begin{array}{c}G F R \\
(\mathrm{ml} / \mathrm{min})\end{array}$} & \multicolumn{4}{|c|}{ Sulfadimethoxine- $\mathrm{N}^{4}$-acetate } & \multirow[b]{2}{*}{$\begin{array}{l}\text { Iodopyracet } \\
P(\mathrm{mg} / \mathrm{ml})\end{array}$} \\
\hline & & & & & $\underset{(\mathrm{mg} / \mathrm{ml})}{U}$ & $\begin{array}{c}P \\
(\mathrm{mg} / \mathrm{ml})\end{array}$ & $\underset{(\mathrm{ml} / \mathrm{min})}{C}$ & $\mathrm{CR}$ & \\
\hline \multirow{3}{*}{ Control } & $(30-20$ & 4.36 & 7.20 & 133.5 & 0.105 & 0.0142 & 32.4 & 0.243 & - \\
\hline & $\{20-10$ & 4.40 & - & 100.4 & 0.074 & 0.0143 & 22.6 & 0.225 & - \\
\hline & $10-0$ & 3.00 & - & 85.5 & 0.080 & 0.0122 & 19.6 & 0.229 & - \\
\hline \multirow{3}{*}{ Exptl. $\left.{ }^{a}\right)$} & $(15-25$ & 3.30 & 7.20 & 83.6 & 0.034 & 0.0168 & 6.5 & 0.078 & 0.6727 \\
\hline & $25-35$ & 2.90 & - & 70.2 & 0.039 & 0.0180 & 6.2 & 0.088 & 0.7587 \\
\hline & $35-45$ & 3.20 & 7.35 & 90.1 & 0.043 & 0.0184 & 7.4 & 0.082 & 0.6878 \\
\hline
\end{tabular}

dog: \& $14.3 \mathrm{~kg}$ (dog $\mathrm{E}$ in Fig. 2)

a) iodopyracet: $2.97 \mathrm{~g}$ i.v., $95.3 \mathrm{mg} / \mathrm{min}$ infusion

TABLE III. Clearance Ratio of Sulfadimethoxine- $\mathrm{N}^{4}$-glucuronide before and after Blockade of Proximal Tubular Secretion

\begin{tabular}{|c|c|c|c|c|c|c|c|c|c|}
\hline & \multirow[b]{2}{*}{$\begin{array}{l}\text { Time } \\
(\min )\end{array}$} & \multirow[b]{2}{*}{$\begin{array}{c}V \\
(\mathrm{ml} / \mathrm{min})\end{array}$} & \multirow[b]{2}{*}{$\begin{array}{l}\text { Urine } \\
\mathrm{pH}\end{array}$} & \multirow[b]{2}{*}{$\begin{array}{c}G F R \\
(\mathrm{ml} / \mathrm{min})\end{array}$} & \multicolumn{4}{|c|}{ Sulfadimethoxine- $\mathrm{N}^{4}$-glucuronide } & \multirow[b]{2}{*}{$\begin{array}{l}\text { Iodopyracet } \\
P(\mathrm{mg} / \mathrm{ml})\end{array}$} \\
\hline & & & & & $\begin{array}{c}U \\
(\mathrm{mg} / \mathrm{ml})\end{array}$ & $\underset{(\mathrm{mg} / \mathrm{ml})}{P}$ & $\underset{(\mathrm{ml} / \mathrm{min})}{C}$ & $\mathrm{CR}$ & \\
\hline \multirow{3}{*}{ Control } & $(30-20$ & 2.36 & 7.05 & 58.5 & 0.464 & 0.0562 & 19.5 & 0.3333 & - \\
\hline & $\{20-10$ & 2.64 & - & 52.2 & 0.480 & 0.0597 & 21.2 & 0.4061 & - \\
\hline & $10-0$ & 2.72 & - & 54.4 & 0.536 & 0.0640 & 22.8 & 0.4191 & - \\
\hline \multirow{3}{*}{ Exptl. ${ }^{a}$} & $(15-25$ & 3.62 & 7.10 & 71.6 & 0.387 & 0.0666 & 21.0 & 0.2933 & 0.6342 \\
\hline & $\{25-35$ & 3.30 & - & 33.4 & 0.223 & 0.0640 & 11.5 & 0.3443 & 0.6056 \\
\hline & {$[35-45$} & 3.04 & - & 66.6 & 0.431 & 0.0658 & 19.9 & 0.2988 & 0.5877 \\
\hline
\end{tabular}

iodopyracet was not observed. This fact suggests that glucuronidation of $\mathrm{N}^{1}$-position of sulfadimethoxine exhibits more affinity for glomerular filtration rather than proximal tubular secretion. Intravenously injected sulfadimethoxine- $\mathrm{N}^{1}$-glucuronide was certified to resist hydrolysis in vivo and excreted as unchanged form.

In the above mentioned results of renal clearance experiments using dogs, it was assured that clearance ratio of three biotransformed products of sulfadimethoxine exceeds over the clearance ratio of sulfadimethoxine. Particularly, clearance ratio of sulfadimethoxine- $\mathrm{N}^{1}$-glucuronide extremely exceeded over that of sulfadimethoxine and the other two biotransformed

TABLE IV. Clearance Ratio of Sulfadimethoxine- $\mathbf{N}^{1}$-glucuronide before and after Blockade of Proximal Tubular Secretion

\begin{tabular}{|c|c|c|c|c|c|c|c|c|c|}
\hline & \multirow{2}{*}{$\begin{array}{l}\text { Time } \\
(\min )\end{array}$} & \multirow{2}{*}{$\underset{(\mathrm{ml} / \mathrm{min})}{V}$} & \multirow{2}{*}{$\begin{array}{l}\text { Urine } \\
\mathrm{pH}\end{array}$} & \multirow{2}{*}{$\begin{array}{c}G F R \\
(\mathrm{ml} / \mathrm{min})\end{array}$} & \multicolumn{4}{|c|}{ Sulfadimethoxine- $\mathrm{N}^{1}$-glucuronide } & \multirow{2}{*}{$\begin{array}{l}\text { Iodopyracet } \\
P(\mathrm{mg} / \mathrm{ml})\end{array}$} \\
\hline & & & & & $\begin{array}{c}U \\
(\mathrm{mg} / \mathrm{ml})\end{array}$ & $\begin{array}{c}P \\
(\mathrm{mg} / \mathrm{ml})\end{array}$ & $\begin{array}{c}C \\
(\mathrm{ml} / \mathrm{min})\end{array}$ & $\mathrm{CR}$ & \\
\hline \multirow{4}{*}{ Control } & $(30-20$ & 4.08 & 7.75 & 73.4 & 0.043 & 0.0036 & 48.5 & 0.661 & - \\
\hline & $\{20-10$ & 3.76 & - & 81.6 & 0.047 & 0.0038 & 46.1 & 0.565 & - \\
\hline & $10-0$ & 3.60 & - & 103.1 & 0.056 & 0.0037 & 54.4 & 0.528 & - \\
\hline & $(25-35$ & 4.40 & 7.76 & 77.7 & 0.061 & 0.0057 & 47.3 & 0.612 & 0.4627 \\
\hline \multirow[t]{2}{*}{ Exptl. $\left.{ }^{a}\right)$} & $\{35-45$ & 4.30 & - & 77.3 & 0.068 & 0.0058 & 50.1 & 0.648 & 0.4614 \\
\hline & $45-55$ & 4.10 & 7.92 & 78.8 & 0.070 & 0.0061 & 46.9 & $0.59 \overline{5}$ & 0.4746 \\
\hline
\end{tabular}


products. It is needed to be emphasized that any biotransformation of sulfadimethoxine results considerable rise of clearance ratio and the acceleration of renal excretion rate. A conclusion was drawn as to renal transport patterns of sulfadimethoxine and its biotransformed products. Namely, sulfadimethoxine- $\mathrm{N}^{4}$-acetate alone is excreted mainly through proximal tubular secretion. On the contrary, the insufficiency of proximal tubular transport of sulfadimethoxine and sulfadimethoxine- $\mathrm{N}^{1}$-glucuronide were confirmed by our experiments.

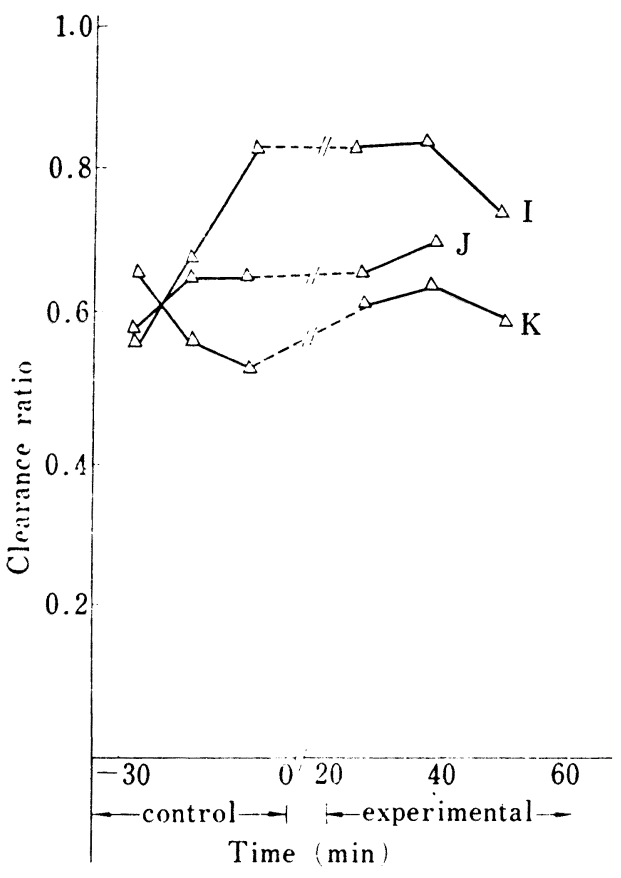

Fig. 4. Clearance Ratio of Sulfadimethoxine$\mathrm{N}^{1}$-glucuronide before and after Blockade of Proximal Tubular Secretion

The lines connect the values for each dog.

$\mathrm{I}: \operatorname{dog}$ o $15.5 \mathrm{~kg} \quad \mathrm{~J}: \log$ o $11.5 \mathrm{~kg} \quad \mathrm{~K}: \operatorname{dog}$ o $16.5 \mathrm{~kg}$

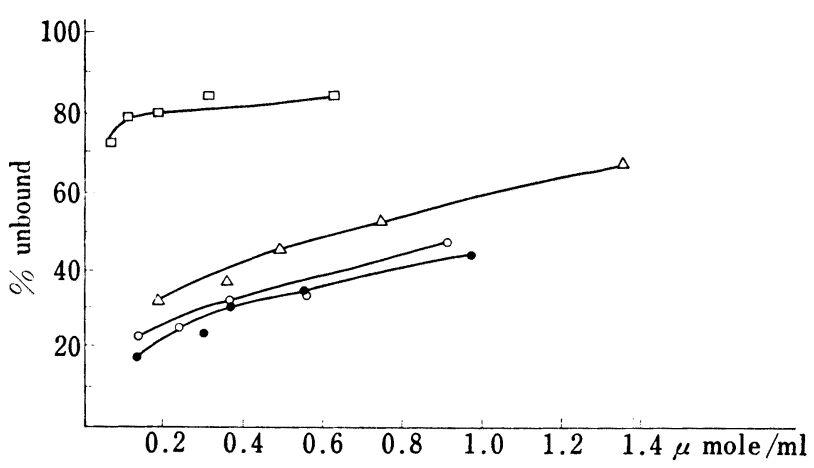

Total concentration in internal compartment (bound and unbound)

Fig. 5. Comparison of the Binding of Sulfadimethoxine, Sulfadimethoxine- $\mathrm{N}^{4}$-acetate, Sulfadimethoxine- $\mathrm{N}^{1}$ glucuronide and Sulfadimethoxine- $\mathrm{N}^{4}$-glucuronide to Dog Plasma Protein

$$
\begin{aligned}
& \text { : } \text { SDM } \\
& \text { : SDM-N } \\
& \square \text { : SDM-acetate } \\
& \triangle \text { : } \mathrm{SDM}^{\mathbf{1}} \text {-glucuronide }
\end{aligned}
$$

\section{Protein Binding of Sulfadimethoxine and Its Biotransformed Products}

Protein binding is also one of the important factors for determining the renal excretion of sulfonamides, because the drug immediately available for renal excretion through glomerular filtration is the portion present in plasma as free form unbound to plasma protein. The binding of sulfadimethoxine and its biotransformed products to dog plasma were investigated in $0.1 \mathrm{~m}$ isotonic phosphate buffer solution at $\mathrm{pH}$ 7.4. As shown in Fig. 5, curved lines were obtained by plotting the percentage unbound as a function of the concentration of sulfonamide present in the inner compartment (bound and unbound). These differences in their affinities for dog plasma protein would play different effects on their renal excretion mechanisms.

Sulfadimethoxine- $\mathrm{N}^{4}$-glucuronide was unstable under the experimental condition of dialysis and about $32.5 \%$ of initial concentration of the substance were hydrolyzed at the end point of incubation time. The data for the substance is the observed values and not corrected.

Previously, Scholtan ${ }^{17}$ ) and Rieder ${ }^{18)}$ reported the protein binding of sulfadimethoxine and its biotransformed products to human plasma. They pointed out that $\mathrm{N}^{4}$-acetylation of

17) W. Scholtan, Arzneimittel-Forsch, 11, 652 (1961).

18) J. Rieder, Arzneimitttel-Eorsch, 13, 84 (1963). 
sulfadimethoxine increased the protein binding, whereas $\mathrm{N}$-glucuronidation of sulfadimethoxine greatly reduced it. As shown in Fig. 5, protein binding of sulfadimethoxine and sulfadimethoxine- $\mathrm{N}^{4}$-acetate in dog plasma is much higher than sulfadimethoxine- $\mathrm{N}^{1}$-glucuronide, which suggests the reduced affinity of sulfadimethoxine- $\mathrm{N}^{1}$-glucuronide to dog plasma protein. Such reduced protein binding of sulfadimethoxine- $\mathrm{N}^{1}$-glucuronide is seemed to be one of the important factors controlling renal excretion rate of the compound. 